\title{
Perspectives of Lithium Mining in Quebec, Potential and Advantages of Integration into a Local Battery Production Chain for Electric Vehicles ${ }^{\dagger}$
}

\author{
Sebastián Ibarra-Gutiérrez ${ }^{1,2, *} \mathbb{0}$, Jocelyn Bouchard ${ }^{1,2,3}$, Marcel Laflamme ${ }^{4}$ and Konstantinos Fytas ${ }^{5}$ \\ 1 Centre de Recherche sur la Géologie et L'ingénierie des Ressources Minérales (E4m), \\ Québec, QC G1V 0A6, Canada; jocelyn.bouchard@gch.ulaval.ca \\ 2 Département de Génie Chimique, Faculté des Sciences et de Génie, Université Laval, \\ Québec, QC G1V 0A6, Canada \\ 3 Laboratoire D'observation et D'optimisation des Procédés (LOOP), Université Laval, \\ Québec, QC G1V 0A6, Canada \\ 4 InnovExplo, Val-d'Or, QC J9P 1S4, Canada; marcel.laflamme@innovexplo.com \\ 5 Département de Génie des Mines, de la Métallurgie et des Matériaux, Université Laval, \\ Québec, QC G1V 0A6, Canada; konstantinos.fytas.1@ulaval.ca \\ * Correspondence: seiba@ulaval.ca \\ + Presented at International Conference on Raw Materials and Circular Economy, Athens, Greece, 5-9 \\ September 2021
}

Citation: Ibarra-Gutiérrez, S.; Bouchard, J.; Laflamme, M.; Fytas, K. Perspectives of Lithium Mining in Quebec, Potential and Advantages of Integration into a Local Battery Production Chain for Electric Vehicles. Mater. Proc. 2021, 5, 33. https:// doi.org/10.3390/materproc2021005033

Academic Editor: Anthimos Xenidis

Published: 29 November 2021

Publisher's Note: MDPI stays neutral with regard to jurisdictional claims in published maps and institutional affiliations.

Copyright: (c) 2021 by the authors. Licensee MDPI, Basel, Switzerland. This article is an open access article distributed under the terms and conditions of the Creative Commons Attribution (CC BY) license (https:// creativecommons.org/licenses/by/ $4.0 /)$.

\begin{abstract}
This paper presents a discussion on Quebec's pegmatite lithium resources and potential markets. It also evaluates the opportunities of lithium battery production for electric vehicles (EV) in the province while reducing greenhouse gas emissions. The paper shows that mining Quebec's lithium ore deposits would be sufficient to satisfy the province's lithium demand and also for exporting abroad lithium-ion batteries. By considering only the projects whose final product is $\mathrm{LMH}$ or LCE, Quebec would be able to produce between 10 and 21 million lithium-ion batteries for electric vehicles with a greenhouse gas emissions footprint of only $43 \%$ of the international average value due to Quebec's hydro power. Finally, considering Quebec's lithium mining project economics, the increased future demand for lithium would render Quebec's lithium pegmatite projects competitive compared with those reported for brine projects.
\end{abstract}

Keywords: lithium; Quebec; mining; electric vehicles; economics; batteries

\section{Introduction}

The rising popularity of electric vehicles (EVs) has put increasing pressure on the demand for lithium carbonates in the last decade. In fact, as EVs become more and more accessible, different applications such as public transit, personal transportation, heavy trucks and even underground mining equipment are considering the electric battery as a viable alternative [1,2]. Lithium-ion batteries are of particular interest because they possess many attractive properties, such as high energy density, low self-discharge, low maintenance and now greatly reduced costs, which have made them superior to other commercial technologies on the market [3]. Thus, it is predicted that lithium production in 2015-2019 will need to more than double by 2025-2030 to keep up with demand [4,5].

Lithium doesn't occur in its metallic form in nature and is instead found in oxidized deposits such as minerals, brines, sedimentary rocks and sea water [6]. Nevertheless, commercial sources of lithium are primarily pegmatites (a hard-rock lithium mineral) or brine deposits [7]. Pegmatite ores follow typical mining and processing routes: standard drilling and blasting, trucking to a central processing facility and, after multiple stages of crushing and grinding, minerals can be liberated from gangue via dense media separation [8]. The brine deposits on the other hand require the naturally occurring solution to be pumped 
into ad hoc ponds in which solar evaporation takes place and concentrate dissolved lithium salts. The process requires a series of such ponds of increasing concentration to upgrade the solution before precipitating the product [9].

Historically, lithium was entirely sourced from traditional pegmatite hard rock mining, but extraction from brine deposits has become increasingly common recently because of lower production costs [10]. Yet, this trend is changing, and now conventional pegmatite projects are seen as economic viable alternatives [11]. The province of Quebec exhibits the most important pegmatite-based lithium mineral reserves in Canada [12]. It also posses the mining ecosystem and experience to integrate its potential lithium production into a whole local added value chain [13]. However, the two ventures most likely to enter the market in a foreseeable future currently face technical and technological challenges. Quebec-based operating lithium mines and battery producing plants thus remain to become reality.

Since Quebec's has promoted policies regarding the evaluation of the province's capacity to produce lithium for use in EV batteries as a societal choice, this paper focuses on analyzing the province's battery production capacity and associated GHG emissions, while seeking to compare the project economics of local pegmatite projects with brine projects abroad. All of this, with the aim of identifying the perspectives, the potential and the advantages of lithium mining in Quebec in order to integrate its final products into a local battery production chain for the EV market.

\section{Materials and Methods}

This paper summarizes and highlights the most important aspects that emerged from research on lithium mining in Quebec, for which more details are available in three previous publications [12-14]. The analysis examines three lithium hard rock projects in Quebec and five brine mining projects located in Argentina and Chile, all of them with proven mineral reserves. Only the considered data were previously reported in feasibility of pre-feasibility technical reports complying with the Canadian standard NI 43-101 or any recognized equivalent in in the last ten years. This consideration aims at referring to only up to date information about projects that could start production in a foreseeable future.

Firstly, the values of the considered brine and Quebec potential operations were compared, highlighting the different associated project economics. The purpose of this juxtaposition was to identify opportunities from which a Quebec lithium production could leverage to gain additional economic benefits.

Secondly, the lithium-ion batteries potentially produced in Quebec for EVs was evaluated, considering only proven and probable mineral reserves of the province mining projects targeting either lithium carbonate, reported as lithium carbonate equivalent (LCE), or lithium hydroxide monohydrate (LMH) as a final product. For this purpose, a weighted capacity of $62.5 \mathrm{kWh}$ was selected based on the analysis of $88 \%$ of the most popular EV models in Quebec in 2020. Additionally, the required lithium in a battery is assumed to lay within 190 and $380 \mathrm{~g} \mathrm{Li} / \mathrm{kWh}$ [15]. The production figures are reported in terms of LCE or LMH applying a conversion factor of 5.323 and 0.880 , respectively [16]. All calculations assume that the mining projects start production at the same time, and that they reach the projected processing rate according to their feasibility studies.

Lastly, Table 1 summarizes the energy required to produce one ton of LMH from a spodumene concentrate in Quebec [17]. The GHG emissions calculations use the following reference values:

- The energy density of natural gas in Quebec is $37.89 \mathrm{MJ} / \mathrm{m}^{3}$ [18];

- The emission factor for natural gas is $1.94 \mathrm{~kg} \mathrm{CO}_{2} / \mathrm{m}^{3}$ [19];

- The emission factor for the electricity grid in Quebec is $1.2 \mathrm{~g} \mathrm{CO}_{2} / \mathrm{kWh}$ [20];

- The emissions for assembly a single lithium-ion battery is $141.5 \mathrm{~kg} \mathrm{CO}_{2}$ [21]. 
Table 1. Energy inputs and GHG emissions to produce $1 \mathrm{t}$ of LMH from spodumene concentrate for the Whabouchi project in Quebec [12].

\begin{tabular}{ccc}
\hline Energy Input & Amount & Emission \\
\hline Electricity power (concentration plant) & $7610 \mathrm{MJ}$ & $2.54 \mathrm{~kg} \mathrm{CO}_{2}$ \\
Electricity power (electrochemical plant) & $32.85 \mathrm{GJ}$ & $10.95 \mathrm{~kg} \mathrm{CO}_{2}$ \\
Natural gas (electrochemical plant) & $36.35 \mathrm{GJ}$ & $1861.14 \mathrm{~kg} \mathrm{CO}_{2}$ \\
Total & $69.21 \mathrm{GJ}$ & $1874.63 \mathrm{~kg} \mathrm{CO}_{2}$ \\
\hline
\end{tabular}

\section{Results}

Table 2 provides the information relevant for the purpose of comparing the mining project economics, and Figure 1 juxtaposes the capital (CAPEX) and operational expenditures (OPEX) over the respective mine life. The unit operating costs for the projects located in Argentina, Bolivia and Chile, a.k.a. the Lithium Triangle, fall in the range of 3000-3600 USD/t LCE, except for the MSB Blanco (Chile), slightly higher at 3900 USD/t LCE. Both Quebec-based projects also lie within this range. As shown in Figure 1, Authier Lithium and Quebec Lithium exhibit lower CAPEX than all the South American projects. The electrochemical processing facility for Wabouchi's concentrate obviously contributes to the total capital cost to a large extent, thus making the comparison irrelevant.

Table 3 presents the total number of lithium-ion batteries and associated GHG emissions that would result in Quebec from the total production of lithium from the Whabouchi and Quebec Lithium projects over a 33-year period. In this scenario, the production would reach figures from 10 to 21 million of batteries, with GHG emissions varying from 3.80 to $5.34 \mathrm{M} \mathrm{t} \mathrm{CO}_{2}$ eq., respectively.

Table 2. Features and project economics from lithium mining projects. Elaborated with data from feasibility studies [17,22-28].

\begin{tabular}{|c|c|c|c|c|c|c|c|}
\hline Project Name & Location & $\begin{array}{l}\text { Life of Mine } \\
\text { (Years) }\end{array}$ & Final Product & $\begin{array}{c}\text { Unit } \\
\text { Operating } \\
\text { Cost (USD/t } \\
\text { LCE) }^{1}\end{array}$ & $\begin{array}{l}\text { Pre-Tax NPV } \\
\quad(8 \%)^{2}\end{array}$ & $\begin{array}{c}\text { Pre-Tax IRR } \\
(\%)\end{array}$ & $\begin{array}{c}\text { Payback } \\
\text { Period } \\
\text { (Years) }\end{array}$ \\
\hline Authier Lithium & Quebec & 14 & $\begin{array}{l}\text { 114,116 t/y of spod. } \\
\text { concentrate }\end{array}$ & - & 216 M CAD & 33.90 & 4.0 \\
\hline Quebec Lithium & Quebec & 15 & 20,000 t LCE/y & 3596.60 & 365 M CAD & 32.00 & 4.0 \\
\hline Whabouchi & Quebec & 33 & 37,000 t LMH/y & $3640.87^{3}$ & 3128 M CAD & 30.30 & 4.5 \\
\hline 3Q Project & Argentina & 35 & 20,000 t LCE/y & 2963.87 & 1547 M USD & 60.30 & 1.7 \\
\hline Cauchari JV & Argentina & 31 & 25,000 t LCE/y & 3421.08 & 1158 M USD & 26.20 & 4.6 \\
\hline Cauchari-Olaroz & Argentina & 40 & 40,000 t LCE/y & 3622.43 & 2774 M USD & 37.99 & 2.8 \\
\hline Pastos Grandes & Argentina & 40 & 24,000 t LCE/y & 3438.52 & 1588 M USD & 28.10 & 5.3 \\
\hline MSB Blanco & Chile & 20 & 20,000 t LCE/y & 3903.30 & 1286 M USD & 23.80 & 4.1 \\
\hline
\end{tabular}

${ }^{1}$ For the purpose of comparison, all values have been discounted to December 2020 U.S. dollars using the rates listed on the United States Department of Labor [29] from the dates indicated in the respective feasibility studies. ${ }^{2}$ Presented values have not been discounted and are reported according to the date of the feasibility studies. ${ }^{3} \mathrm{USD} / \mathrm{t} \mathrm{LMH}$.

Table 3. Number of potential $62.5 \mathrm{kWh}$ EV batteries produced from Quebec LHM production and associated GHG emissions.

\begin{tabular}{|c|c|c|c|c|c|}
\hline \multirow{2}{*}{ Total Production (t Li) } & \multirow{2}{*}{ Lithium Consumption (g Li/kWh) } & \multirow{2}{*}{$\mathbf{N}^{\circ}$ of Batteries } & \multicolumn{3}{|c|}{ GHG Emissions (Mt of $\mathrm{CO}_{2}$ eq.) } \\
\hline & & & Production & Assembly & Total \\
\hline \multirow{2}{*}{257,843} & 190 & $21,713,122$ & \multirow{2}{*}{2.26} & 3.08 & 5.34 \\
\hline & 380 & $10,856,561$ & & 1.54 & 3.80 \\
\hline
\end{tabular}




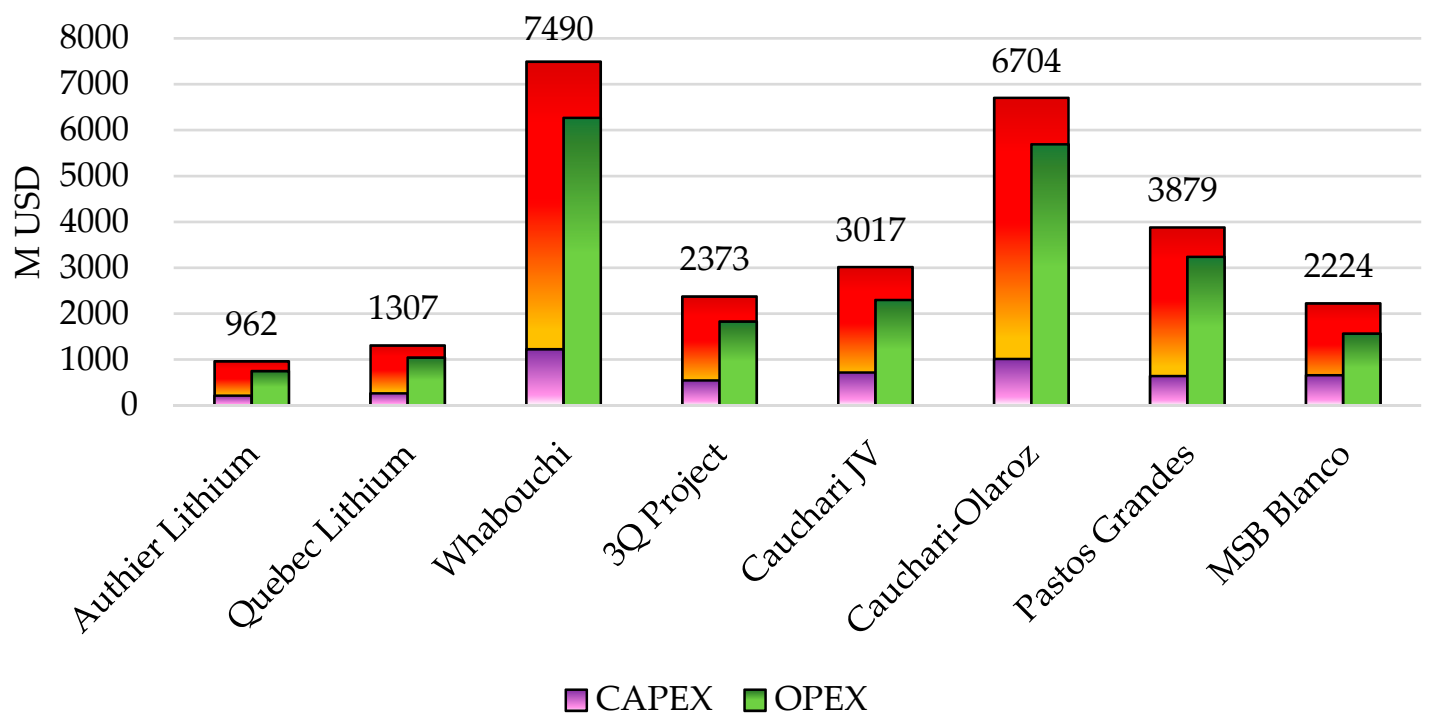

Figure 1. CAPEX and OPEX over the life of mine from the analyzed lithium mining projects (the red bar represents the sum of the CAPEX and OPEX).

\section{Discussion}

Table 1 shows that current brine processing projects tend to be of larger scale, compared to Quebec's hard rock projects, when considering the life of mine, capital costs involved and NPV. The life of mine of four of them (out of five) exceeds 30 years, whereas two out of three spodumene operations would only last 14-15 years. The NPV of lithium mining projects from pegmatites in Quebec is much lower than that of lithium mining projects from brines. Whabouchi stands alone with a much larger deposit, exhibiting mineral reserves to contemplate over 30 years of operations. All Quebec projects provide consistent IRR between 30-34\%, while a greater variability is observed for brine projects, ranging from $24-61 \%$.

As presented in Figure 1, CAPEX associated with each project should not be overlooked. Quebec projects, which for the most part have lower capital costs and a shorter mine life, may represent a less risky option, although they come with a lower NPV. Results also demonstrate that the unit operating costs of Quebec Lithium (3600 USD/t LCE) compare with those of projects in the upper range in Argentina, i.e., Cauchari JV ( 3400 USD/t LCE), Pastos Grandes ( 3400 USD/t LCE), Cauchari-Olaroz (3620 USD/t LCE) and MSB Blanco (3900 USD/t LCE). 3Q on the other hand, at $~ 3000 \mathrm{USD} / \mathrm{t}$ LCE, notably exhibits a more competitive figure.

In this regard, improvements in process control show great promise to increase the benefits - through additional unit metal recovery — and reduce the energy consumption of mineral processing operations, which could result in significantly lower operating costs for pegmatite projects. Future work should also explore the significance of the location and other market factors in the decision-making for a given investment. The comparison with other hard rock potential operations, e.g., in Australia and China, would obviously be very informative in this regard.

It is worth noticing that Quebec mineral reserves exceed to a large extent the domestic needs should manufacturing lithium batteries for EVs from locally produced LCE/LMH be contemplated. Quebec would therefore mostly rely on the export market, hence highlighting the interest to further develop sector to produce finish goods: lithium-ion batteries. The possibility to integrate the neighboring American and Ontario automobile industry clearly makes a compelling argument for such a venture.

Regarding the GHG emissions, producing lithium-ion batteries in Quebec would emit $1.9 \mathrm{t}$ of equivalent $\mathrm{CO}_{2}$ at the production stage. This value is about $43 \%$ of the $2.8-2.9 \mathrm{t}$ reported in the literature [21]. However, this estimate only considers energy requirements for Li and therefore, other contributions, such as electrolyte and other components, could 
potentially be added. Moreover, it emphasized that the production of 10 to 21 million of lithium-ion batteries for EVs, considering lithium production and assembly, would produce between 3.80 and $5.34 \mathrm{Mt}$ of $\mathrm{CO}_{2}$ eq. As a comparison, the entire fleet of personal internal combustion engine vehicles in Quebec emits about $17.1 \mathrm{Mt}$ of equivalent $\mathrm{CO}_{2}$ annually [12]

Lastly, it should be noted that several factors contribute to bringing the operating costs of Quebec projects closer to those of brine projects and to reducing GHG emissions in the context of local lithium-ion battery production:

- Affordable hydro power in the province;

- Low emission factor for the electricity grid;

- Established public infrastructures (power lines, highways, water supplies, etc.) for projects close to urban centers located in the Abitibi-Témiscamingue region;

- Historical mining expertise and a qualified local workforce.

\section{Conclusions}

This work analyzed the perspectives and the potential of the exploitation of pegmatite deposits in Quebec in order to integrate this lithium production in a context of local production of lithium-ion batteries for EVs. The number of such batteries has been estimated at between 10 and 21 million, with a small environmental footprint.

It is important to note that the global market premises still hold, and even if a given mining project is attractive on an environmental basis, as could be the case for the Quebec lithium mining projects, the profitability and competitivity will ultimately decide its faith. Future work will aim at studying this specific issue. Despite these limitations, this study provides a context for compiling, interpreting and comparing results from different projects and highlights two main aspects: (i) the operating cost of obtaining lithium carbonate from brines is no longer necessarily lower than from pegmatite mining, and (ii) the province's renewable energy sources provide a significant GHG emission advantage for lithium-ion battery production when it comes to energy intensive processes.

Author Contributions: Conceptualization and methodology, S.I.-G., J.B., M.L. and K.F.; validation, J.B., M.L. and K.F.; formal analysis, investigation and writing-original draft preparation, S.I.-G.; writing-review and editing, J.B., M.L., K.F. and S.I.-G.; supervision, J.B., M.L. and K.F.; project administration and funding acquisition, J.B. All authors have read and agreed to the published version of the manuscript.

Funding: This research was funded by Fonds de recherche du Québec-Nature et technologie (FRQNT), the Fonds Vert du Québec and Nemaska Lithium.

Institutional Review Board Statement: Not applicable.

Informed Consent Statement: Not applicable.

Data Availability Statement: Data from Technical Reports is available online according to the policies of the System for Electronic Document Analysis and Retrieval (SEDAR) on www.sedar.com.

Conflicts of Interest: The authors declare no conflict of interest. The funders had no role in the design of the study; in the collection, analyses, or interpretation of data; in the writing of the manuscript, or in the decision to publish the results.

\section{References}

1. Lopez-Pacheco, A. The drive to electric. CIM Mag. 2020, 15, 60-63.

2. Nykvist, B.; Olsson, O. The feasibility of heavy battery electric trucks. Joule 2021, 5, 901-913. [CrossRef]

3. IRENA. Electricity Storage and Renewables: Costs and Markets to 2030; International Renewable Energy Agency: Abu Dhabi, United Arab Emirates, 2017. Available online: https://www.irena.org/-/media/Files/IRENA/Agency/Publication/2017/Oct/IRENA_ Electricity_Storage_Costs_2017.pdf (accessed on 28 May 2021).

4. Welhan, N.J. SME Mineral Processing and Extractive Metallurgy Handbook; Chapter 12.20_Lithium; Society for Mining, Metallurgy and Exploration, SME: Englewood, CO, USA, 2019; pp. 1839-1853, ISBN 978-0-87335-385-4.

5. IEA. Global EV Outlook 2020; IEA: Paris, France, 2020. Available online: https://www.iea.org/reports/global-ev-outlook-2020 (accessed on 12 May 2021). 
6. Speirs, J.; Contestabile, M. The Future of Lithium Availability for Electric Vehicle Batteries. In Behaviour of Lithium-Ion Batteries in Electric Vehicles: Battery Health, Performance, Safety, and Cost; Pistoia, G., Liaw, B., Eds.; Springer International Publishing: New York, NY, USA, 2018.

7. Garret, D. Handbook of Lithium and Natural Calcium Chloride, 1st ed.; Elsevier: New York, NY, USA, 2004; 488p, ISBN 9780122761522.

8. Deutsche Bank. Lithium 101. Deutsche Bank Markets Research Report; Deutsche Bank AG/Sydney: Sydney, Australia, 2016; 177p.

9. Kavanagh, L.; Keohane, J.; Garcia Cabellos, G.; Lloyd, A.; Cleary, J. Global Lithium Sources-Industrial Use and Future in the Electric Vehicle Industry: A Review. Resources 2018, 7, 57. [CrossRef]

10. BGS. Lithium. Commodity Profile, Produced by the British Geological Survey. 2016. Available online: http:/ / www.mineralsuk. com (accessed on 3 June 2021).

11. Sterba, J.; Krzemien, A.; Riesgo-Fernández, P.; García-Miranda, C.E.; Valverde, G.F. Lithium mining: Accelerating the transition to sustainable energy. Resour. Policy 2019, 62, 416-426. [CrossRef]

12. Ibarra-Gutiérrez, S.; Bouchard, J.; Laflamme, M.; Fytas, K. Assessing the potential of Quebec lithium industry: Mineral Reserves, lithium-ion batteries production and GHG emissions. Resour. Policy 2021, 74, 102371. [CrossRef]

13. Ibarra-Gutiérrez, S.; Bouchard, J.; Laflamme, M.; Fytas, K. The Potential of Lithium in Quebec for the Electric Vehicle Market: State of the Art, Opportunities and Challenges. Int. J. Mining. Reclam. Environ. 2020. Manuscript accepted for publication. [CrossRef]

14. Ibarra-Gutiérrez, S.; Bouchard, J.; Laflamme, M.; Fytas, K. Project economics of lithium mines in Quebec: A critical review. Extr. Ind. Soc. 2021, in press. [CrossRef]

15. Speirs, J.; Contestabile, M.; Houari, Y.; Gross, R. The future of lithium availability for electric vehicle batteries. Renew. Sustain. Energy Rev. 2014, 35, 183-193. [CrossRef]

16. Canaccord. Start Me Up-Electric vehicles \& Grid storage to drive Lithium demand, Specialty Minerals and Metals-Industry Overview, Canaccord Genuity. Available online: https:/ / rockstone-research.com/images/PDF/CanaccordLithiumResearchMay2 016.pdf (accessed on 17 May 2016).

17. Nemaska Lithium. NI 43-101 Technical Report, Report on the Estimate to Complete for the Whabouchi Lithium Mine and Shawinigan Electrochemical Plant, Nemaska Project, Technical Report; SEDAR: Jujuy, Argentina, 2019; 563p.

18. Energir. Natural Gas Supply in Québec. Technical Properties. 2021. Available online: https://www.energir.com/en/majorindustries/natural-gas-quebec/natural-gas-properties/ (accessed on 9 June 2021).

19. EPA. AVERT, U.S. National Weighted Average CO2 Marginal Emission Rate, Year 2018 Data; U.S. Environmental Protection Agency: Washington, DC, USA, 2019.

20. CER. Canada's Renewable Power Landscape 2017-Energy Market Analysis. Canada Energy Regulator, 2020. Available online: https:/ / www.cer-rec.gc.ca/nrg/sttstc/lctrct/index-eng.html (accessed on 9 June 2021).

21. Qiao, Q.; Zhao, F.; Liu, Z.; Jiang, S.; Hao, H. Comparative Study on Life Cycle $\mathrm{CO}_{2}$ Emissions from the Production of Electric and Conventional Vehicles in China. Energy Procedia 2017, 105, 3584-3595. [CrossRef]

22. Sayona Quebec. Authier Lithium Project. Updated Definitive Feasibility Study; Idem: Tokyo, Japan, 2019; 419p.

23. Canada Lithium Corp. Feasibility Study Update NI 43-101 Technical Report, Quebec Lithium Project, La Corne Township, Quebec; Idem: Tokyo, Japan, 2012; 184p.

24. Millennial Lithium. Feasibility Study of the Pastos Grandes Project, Technical Report, Canadian Standard NI 43-101; SEDAR: Salta, Argentina, 2019; 650p.

25. Minera Salar Blanco. Definitive Feasibility Study of MSB Blanco Lithium Carbonate Project, Technical Report, Canadian Standard NI 43-101; SEDAR: Atacama Region, Chile, 2019; 389p.

26. Advantage Lithium. Prefeasibility Study of the Cauchari JV Lithium Project; SEDAR: Jujuy, Argentina, 2019; 280p.

27. Lithium Americas. NI 43-101 Technical Report, Updated Feasibility Study and Mineral Reserve Estimation to Support 40,000 tpa Lithium Carbonate Production at the Cauchari-Olaroz Salars; SEDAR: Jujuy, Argentina, 2019; 387p.

28. NEO Lithium Corp. Preliminary Feasibility Study—3Q Project, NI 43-101 Technical Report; NEO Lithium Corp: Catamarca, Argentina, 2019; 368p.

29. U.S. Bureau of Labor Statistics. CPI Inflation Calculator. 2021. Available online: https:/ / www.bls.gov/data/inflation_calculator. $\mathrm{htm}$ (accessed on 10 June 2021). 